\title{
PENGARUH CAR, DANA PIHAK KETIGA, UKURAN BANK, DAN LDR TERHADAP PROFITABILITAS BANK PERKREDITAN RAKYAT
}

\author{
Kadek Widya Astutiningsih ${ }^{1}$ \\ I Gde Kajeng Baskara ${ }^{2}$
}

\author{
${ }^{1,2}$ Fakultas Ekonomi dan Bisnis Universitas Udayana, Bali, Indonesia \\ e-mail: widyaastutiningsih05@gmail.com
}

\begin{abstract}
ABSTRAK
Tujuan penelitian ini adalah untuk mengetahui pengaruh Capital Adequacy Ratio, Dana Pihak Ketiga, Ukuran Bank, dan Loan to Deposit Ratio terhadap Profitabilitas. Penelitian dilakukan pada Bank Pekreditan Rakyat (BPR) di Kabupaten Badung dengan menggunakan laporan keuangan yang dipublikasikan. Populasi dalam penelitian ini adalah seluruh BPR di Kabupaten Badung periode 2014-2016 yaitu sebanyak 52 BPR. Metode penentuan sampel yang digunakan adalah metode purposive sampling. Sampel yang didapat berjumlah 48 sampel. Hasil penelitian menunjukkan bahwa Capital Adequacy Ratio (CAR), Ukuran Bank, dan Loan to Deposit Ratio (LDR) berpengaruh positif dan signifikan terhadap Profitabilitas BPR di Kabupaten Badung selama periode 2014-2016. Sedangkan dana pihak ketiga tidak berpengaruh signifikan terhadap profitabilitas BPR di Kabupaten Badung selama periode 2014-2016.
\end{abstract}

Kata kunci: CAR, ukuran bank, LDR, profitabilitas

\begin{abstract}
The research objective is to determine the effect of Capital Adequacy Ratio, Third Party Funds, Bank Size, and Loan to Deposit Ratio on Profitability. The location of the study was conducted at the Bank Perkreditan Rakyat (BPR) or rural bank in Badung Regency using published financial reports. The population in this study were all BPRs in Badung Regency in the period of 2014-2016 which amounted to 52 BPRs. The sample determination method used is purposive sampling method. The sample obtained were 48 samples. The results of this study indicate that the Capital Adequacy Ratio (CAR), Bank Size, and Loan to Deposit Ratio (LDR) have a positive and significant effect on the profitability of rural banks in Badung Regency during the 2014-2016 period. While third party funds do not have a significant effect on the profitability of rural banks in Badung Regency.
\end{abstract}

Keywords: CAR, bank size, LDR, profitability 


\section{PENDAHULUAN}

Sebagai lembaga keuangan yang berorientasi bisnis, kegiatan bank seharihari tidak akan terlepas dari bidang keuangan. Kegiatan perbankan yang paling pokok adalah membeli uang dengan cara menghimpun dana dari masyarakat luas. Kemudian menjual uang yang berhasil dihimpun dengan cara menyalurkan kembali kepada masyarakat melalui pemberian pinjaman atau kredit. Dari kegiatan jual beli uang inilah bank akan memperoleh keuntungan yaitu dari selisih harga beli (bunga simpanan) dengan harga jual (bunga pinjaman). Disamping itu kegiatan bank lainnya dalam rangka mendukung kegiatan menghimpun dan menyalurkan dana adalah memberikan jasa-jasa lainnya. Kegiatan ini ditujukan untuk memperlancar kegiatan menghimpun dan menyalurkan dana.

Peranan perbankan dalam memajukan perekonomian suatu negara sangatlah besar, kita tidak akan lepas dari dunia perbankan jika hendak menjalani aktivitas keuangan, baik perorangan maupun lembaga, baik sosial atau perusahaan (Kasmir, 2014:32). Bank untuk bisa menjaga kepercayaan masyarakat, harus menjaga kinerja keuangannya (Anggreni, 2014). Sektor perbankan dalam sistem keuangan memegang peranan penting sebagai lembaga intermediasi. Perbankan memediasi antara masyarakat yang memiliki kelebihan dana dengan masyarakat yang memerlukan dana. Bank dikenal sebagai lembaga keuangan yang kegiatan utamanya yaitu menghimpun dana dari masyarakat, menyalurkan dana kepada masyarakat, dan melakukan jasa-jasa lain dibidang perbankan.

Bank merupakan industri yang dalam kegiatan usahanya mengandalkan kepercayaan masyarakat (Kasmir, 2014). Bank Perkreditan Rakyat (BPR) adalah 
lembaga keuangan bank yang menerima simpanan hanya dalam bentuk deposito berjangka, tabungan, dan atau bentuk lainnya yang dipersamakan dengan itu dan menyalurkan dana sebagai usaha. Keberadaan BPR sangat membantu usaha mikro, kecil dan menengah karena kegiatan usaha BPR terutama ditujukan untuk melayani usaha-usaha kecil dan masyarakat di pedesaan. Alasan memilih BPR sebagai tempat penelitian karena BPR merupakan obyek yang unik, keberadaannya juga sangat diperlukan dan dipercaya oleh masyarakat khususnya di Kabupaten Badung. Saat ini terdapat 52 BPR di Kabupaten Badung.

Profitabilitas menurut Munawir (2010:33) adalah kemampuan perusahaan untuk menghasilkan laba selama periode tertentu. menurut Fahmi (2011:135) profitabilitas mengukur efektivitas manajemen secara keseluruhan yang ditunjukkan oleh besar kecilnya tingkat keuntungan yang diperoleh dalam hubungannya dengan penjualan maupun investasi. Profitabilitas suatu perusahaan dapat diketahui dengan membandingkan laba yang diperoleh dalam suatu periode tertentu dengan jumlah aktiva atau jumlah modal perusahaan tersebut. Profitabilitas dapat mengetahui tingkat efisiensi BPR dalam memperoleh laba selama periode tertentu dengan modal yang dipergunakan. Aremu et al. (2013) menyatakan tujuan akhir yang ingin dicapai suatu perusahaan yang terpenting adalah memperoleh laba atau keuntungan yang maksimal. Profitabilitas merupakan gambaran bagaimana kemampuan perusahaan dalam pencapaian tujuannya (Raheem and Malik, 2013).

Dalam melakukan kegiatan operasionalnya, bank memiliki tujuan utama yaitu mencapai tingkat profitabilitas yang maksimal. Profitabilitas merupakan 
indikator yang digunakan untuk mengukur kinerja suatu bank dan efektifitas manajemen berdasarkan hasil pengembalian yang dihasilkan dari pinjaman dan investasi. Alat yang digunakan untuk mengukur profitabilitas dalam penelitian ini adalah Return On Assets (ROA). Menurut Surat Edaran Bank Indonesia Nomor 6/23/DPNP tanggal 31 Mei 2014, ROA merupakan rasio antara laba setelah pajak atau Earning After Tax (EAT) terhadap total asset. ROA penting bagi bank karena ROA digunakan untuk mengukur efektivitas perusahaan di dalam menghasilkan keuntungan dengan memanfaatkan aktiva yang dimilikinya. Semakin besar ROA suatu bank, semakin besar pula tingkat keuntungan yang dicapai bank tersebut dan semakin baik pula posisi bank tersebut dari segi penggunaan asset (Dendawijaya, 2009:118). Berdasarkan penelusuran teori dan penelitian terdahulu, diketahui bahwa terdapat beberapa variabel yang berpengaruh terhadap ROA. Penelitian ini mengambil beberapa variabel yang mempengaruhi ROA yaitu Capital Adequacy Ratio (CAR), Dana Pihak Ketiga, Ukuran Bank, dan Loan to Deposit Ratio (LDR).

CAR adalah rasio yang menunjukkan kemampuan bank dalam menyediakan dana atau modal untuk keperluan pengembangan usaha dan menanggung risiko kerugian dana yang disebabkan oleh aktivitas operasional bank (Sari, 2013). Menurut Febrianto dan Muid (2013), semakin tinggi nilai CAR maka menunjukkan semakin baiknya kemampuan finansial bank dalam mengantisipasi kerugian. Dalam perbankan, rasio solvabilitas sama dengan rasio permodalan, yang dapat dihitung dengan CAR. CAR merupakan rasio kecukupan modal bank 
yang kemampuan bank dengan modal yang dimiliki untuk menutupi kemungkinan kerugian dalam perkreditan.

Penelitian sebelumnya mengenai pengaruh CAR terhadap profitabilitas yang dilakukan oleh Mahardian (2008), Purwana (2009), Sapariyah (2010), dan Sudiyatno (2010), menemukan bahwa CAR berpengaruh positif dan signifikan terhadap ROA. Munthopa, Andrew Lipunga (2014) Al-Qudah dan Mahmoud (2013) menemukan bahwa CAR berpengaruh positif terhadap ROA. Hasil penelitian tersebut berbeda dengan penelitian Alper dan Adem (2011) yang menyatakan bahwa CAR tidak memiliki pengaruh penting terhadap profitabilitas. Prasnanugraha (2007) yang menunjukkan bahwa CAR berpengaruh negatif terhadap ROA.

Dana Pihak Ketiga (DPK) adalah dana yang berasal dari masyarakat yang dihimpun dalam bentuk giro (demand deposit), tabungan (saving deposit), dan deposito (time deposit) yang berasal dari perorangan atau badan (Nuritomo, 2014). Dana inilah yang akan digunakan oleh pihak bank untuk bisa dikelola dan diberdayakan sehingga menghasilkan dan dapat digunakan untuk membiayai kegiatan operasional bank. Pihak bank akan menggunakan dana pihak ketiga tersebut dalam bentuk penjualan jasa berupa penyaluran kredit kepada pihak yang membutuhkan modal kredit. Selain untuk mendapatkan pendapatan bunga atas kredit yang disalurkan, hal ini dilakukan untuk mencegah terjadinya pengendapan dana yaitu adanya ketidakseimbangan antara dana yang telah dihimpun dan kredit yang disalurkan oleh pihak bank. DPK merupakan dana yang bersumber dari masyarakat luas dan merupakan sumber penting untuk aktivitas operasional bank 
sekaligus merupakan tolak ukur keberhasilan suatu bank apabila bank dapat menanggung biaya operasinya dari sumber dana ini (Kasmir, 2012:53). Semakin tinggi rasio ini, maka semakin baik tingkat kepercayaan masyarakat terhadap bank yang bersangkutan (Sudiyatno, 2010).

Penelitian yang dilakukan oleh Irianti (2011) menunjukkan bahwa DPK berpengaruh positif dan signifikan terhadap profitabilitas. Sedangkan penelitian yang dilakukan Anggreni (2014) juga menemukan bahwa DPK berpengaruh positif terhadap profitabilitas. Hasil penelitian yang dilakukan oleh Eka Suputra dkk. (2014) menunjukkan bahwa DPK berpengaruh positif dan signifikan terhadap profitabilitas. Hasil penelitian tersebut berbeda dengan penelitian yang dilakukan oleh Cahyadi (2014) yang menyatakan dana pihak ketiga berpengaruh negatif terhadap profitabilitas.

Ukuran bank dalam penelitian ini dilihat berdasarkan besarnya total aktiva yang dimiliki oleh bank. Aktiva merupakan suatu komponen penting dari suatu perusahaan (Ratnawati et al., 2013). Menurut Kosmidou et al. (2008), bank yang lebih besar ukuran assetnya lebih menguntungkan daripada bank yang ukuran assetnya kecil karena ukuran bank yang lebih besar mempunyai tingkat efisiensi yang lebih tinggi. Ukuran bank dapat dinyatakan dengan total aktiva, penjualan dan kapitalisasi pasar. Ketiga variabel ini digunakan untuk menentukan ukuran bank karena dapat mewakili seberapa besar bank tersebut. Ukuran bank didefinisikan sebagai logaritma natural dari nilai pasar ekuitas pada awal tahun (Rashid dan Rahman, 2007). 
Menurut Manuaba (2012), Raj Bhattarai (2016), ukuran bank berpengaruh positif dan signifikan terhadap ROA. Sajid Saeed Muhammad (2014), Nawaf (2015) menemukan bahwa ukuran bank berpengaruh positif dan tidak signifikan terhadap ROA. Trujillo Antonio, Ponce (2013) menemukan bahwa ukuran bank berpengaruh positif terhadap ROA. Berbeda dengan penelitian yang dilakukan oleh Yogi dan Ramantha (2013), Maredza Andrew (2014), Folorunsho Monsuru Ajide (2014) ukuran bank berpengaruh negatif signifikan terhadap ROA.

LDR merupakan rasio yang menunjukkan seberapa besar kemampuan bank membayar kembali penarikan dana yang dilakukan nasabah deposan dengan mengandalkan kredit yang diberikan sebagai sumber likuiditasnya (Sianturi, 2012). LDR adalah suatu pengukuran tradisional yang menunjukkan deposito berjangka, giro, tabungan, dan lain-lain yang digunakan dalam memenuhi permohonan pinjaman (loan requests) nasabahnya. Rasio ini digunakan untuk mengukur tingkat likuiditas. Besar kecilnya rasio LDR suatu bank akan mempengaruhi profitabilitas bank tersebut. Semakin besar jumlah dana yang disalurkan kepada nasabah dalam bentuk kredit maka jumlah dana yang menganggur berkurang dan penghasilan bunga yang diperoleh akan meningkat. Hal ini tentunya akan meningkatkan LDR sehingga profitabilitas bank juga meningkat (Setiadi, 2010).

Menurut penelitian Sapariyah (2010) LDR secara parsial berpengaruh positif dan signifikan terhadap ROA. Penelitian lain yang dilakukan oleh Dewi dan Suartana (2008), Mahardian (2008), Purwana (2009), Susanthi (2010), dan Jantarini (2010) menemukan bahwa LDR berpengaruh signifikan terhadap ROA. 
Dhanuskodi (2014) menemukan bahwa LDR berpengeruh positif dan tidak signifikan terhadap ROA. Buchory Achmad Herry (2015) menemukan bahwa LDR berpengaruh negatif tetapi tidak berpengaruh signifikan terhadap ROA.

Landasan Hukum BPR adalah UU No.7/1992 tentang Perbankan sebagaimana telah diubah dengan UU No.10/1998. Dalam UU tersebut secara tegas disebutkan bahwa BPR adalah Bank yang melaksanakan kegiatan usaha secara konvensional atau berdasarkan prinsip syariah yang dalam kegiatannya tidak memberikan jasa dalam lalu lintas pembayaran. Kegiatan usaha BPR terutama ditujukan untuk melayani usaha-usaha kecil dan masyarakat di daerah pedesaan. Bentuk hukum BPR dapat berupa Perseroan Terbatas, Perusahaan Daerah, atau Koperasi.

Kebijakan Pemerintah untuk menjadikan BPR sebagai Bank Pedesaan dan membatasi BPR untuk tidak beroperasi dengan menerapkan prinsip efisiensi secara penuh, sesungguhnya mengandung maksud yang baik dan membangun desa. BPR yang diarahkan khusus untuk melayani masyarakat pedesaan dan memperhatikan aspek Efektivitas, diharapkan mampu menjadi motor penggerak perekonomian di daerah pedesaan yang diharapkan dapat mendukung pembangunan pedesaan. Pemerintah sebenarnya juga menggunakan instrumen Bank umum untuk membantu perekonomian masyarakat desa, misalnya memberikan ketentuan bahwa bank umum harus menyalurkan $20 \%$ kredit dalam bentuk Kredit Usaha Kecil (KUK). Prinsip efisiensi tetap dijaga secara ketat oleh bank umum, akan tetapi upaya ini terkesan kurang fleksibel bagi rakyat kecil. 
CAR merupakan indikator terhadap kemampuan bank untuk menutupi penurunan aktivanya sebagai akibat dari kerugian-kerugian bank yang disebabkan oleh aktiva berisiko (Dendawijaya, 2005:121). Semakin besar CAR maka ROA yang akan diperoleh bank semakin besar, karena semakin tinggi CAR maka semakin baik kemampuan bank tersebut untuk menanggung risiko dari setiap kredit/aktiva produktif yang berisiko, sehingga kinerja bank juga akan meningkat. Sebaliknya jika CAR menurun maka ROA yang akan diperoleh juga menurun sehingga kinerja bank juga akan menurun.

Penelitian yang dilakukan oleh Mahardian (2008), Purwana (2009), Sapariyah (2010), Sudiyatno (2010) menemukan bahwa CAR berpengaruh positif dan signifikan terhadap ROA. Munthopa, Andrew Lipunga (2014) menemukan bahwa Capital Adequacy Ratio berpengaruh positif terhadap ROA. Hasil serupa juga ditemukan oleh M. Puspitasari Devi and J. Setiadi Nugroho (2015) bahwa CAR berpengaruh positif dan signifikan terhadap ROA.

$\mathrm{H}_{1}$ : CAR berpengaruh positif signifikan terhadap profitabilitas Bank Perkreditan Rakyat di Kabupaten Badung.

Sumber Dana Pihak Ketiga merupakan sumber dana terpenting bagi kegiatan operasi suatu bank dan merupakan ukuran keberhasilan bank jika mampu membiayai operasinya dari sumber dana ini (Kasmir, 2012). Pentingnya sumber dana dari masyarakat luas disebabkan sumber dana dari masyarakat luas merupakan sumber dana yang paling utama bagi bank. Dana-dana yang dihimpun dari masyarakat merupakan sumber dana yang terbesar yang paling diandalkan oleh Bank. Bank bertugas memberikan pelayanan kepada masyarakat, bank harus selalu berada di tengah masyarakat agar arus uang dari masyarakat yang kelebihan 
dana dapat disalurkan kepada pihak yang kekurangan dana (Rusdiana, 2012). DPK adalah pangsa pasar dana pihak ketiga yang dihimpun oleh masing-masing bank secara indvidu. Semakin tinggi rasio ini, maka semakin baik tingkat kepercayaan masyarakat terhadap bank yang bersangkutan.

Penelitian yang dilakukan oleh Irianti (2011), Eka Suputra dkk. (2014) menunjukkan hasil bahwa DPK berpengaruh positif dan signifikan terhadap profitabilitas. Penelitian yang dilakukan Anggreni (2014) menyatakan bahwa DPK berpengaruh positif terhadap profitabilitas.

$\mathrm{H}_{2}$ : DPK berpengaruh positif signifikan terhadap profitabilitas Bank Perkreditan Rakyat di Kabupaten Badung.

Menurut Ugur dan Erkus (2010), meningkatnya ukuran perbankan akan meningkatkan biaya operasional bank, sehingga margin bunga bank juga meningkat. Bank yang berukuran besar (aset yang besar) cenderung menerapkan margin yang besar juga. Namun semakin besar ukuran bank persero (size) yang ditunjukkan dengan kepemilikan total aset yang besar, juga memiliki peluang yang lebih besar dalam meningkatkan beban yang harus ditanggung oleh pihak bank persero.

Menurut Manuaba (2012) dan Raj Bhattarai (2016), ukuran bank berpengaruh positif dan signifikan terhadap ROA. Trujillo Antonio, Ponce (2013) menemukan bahwa ukuran bank berpengaruh positif terhadap ROA.

$\mathrm{H}_{3}$ : Ukuran bank berpengaruh positif signifikan terhadap profitabilitas Bank Perkreditan Rakyat di Kabupaten Badung.

LDR merupakan kemampuan bank dalam membayar kembali penarikan dana yang dilakukan deposan dengan mengandalkan kredit yang diberikan sebagai sumber likuiditasnya (Dendawijaya, 2005:116). Semakin tinggi LDR 
maka laba perusahaan semakin meningkat dengan asumsi bank tersebut mampu menyalurkan kredit dengan efektif, sehingga jumlah kredit macetnya akan kecil. Hal ini menunjukkan bahwa semakin tinggi LDR sampai dengan batas tertentu maka akan semakin banyak dana yang disalurkan dalam bentuk kredit maka akan meningkatkan pendapatan bunga sehingga ROA semakin tinggi.

Menurut penelitian Sapariyah (2010) LDR secara parsial berpengaruh positif dan signifikan terhadap ROA. Penelitian lain yang dilakukan oleh Dewi dan Suartana (2008), Mahardian (2008), Purwana (2009), Susanthi (2010), dan Jantarini (2010) menemukan bahwa LDR berpengaruh signifikan terhadap ROA. Dhanuskodi Rengasamy (2014) menemukan bahwa LDR berpengaruh positif dan tidak signifikan terhadap ROA. Dhanuskodi Rengasamy (2014) menemukan bahwa LDR berpengeruh positif dan tidak signifikan terhadap ROA.

$\mathrm{H}_{4}$ : LDR berpengaruh positif signifikan terhadap profitabilitas Bank Perkreditan Rakyat di Kabupaten Badung.

\section{METODE PENELITIAN}

Lokasi pada penelitian ini dilakukan pada Bank Pekreditan Rakyat (BPR) di-Kabupaten Badung dengan menggunakan laporan keuangan yang dipublikasikan di OJK. Variabel Independen $(\mathrm{X})$ yang digunakan dalam penelitian ini adalah CAR, DPK, ukuran bank, dan LDR. Variabel Dependen (Y) pada penelitian ini adalah Profitabilitas yang diukur dengan ROA.

Dalam penelitian ini profitabilitas diproksikan dengan ROA pada Bank Perkreditan Rakyat. ROA dirumuskan sebagai berikut (Brigham dan Houston, 2006:107).

$$
\mathrm{ROA}=\frac{\mathrm{L} \quad \mathrm{S} \quad \mathrm{P}}{\mathrm{T} \quad \mathrm{A}} x 100 \%
$$


Modal bank disediakan untuk keperluan pengembangan usaha dan menampung risiko kerugian dana yang diakibatkan oleh kerugian operasi bank. Rasio ini dapat diperoleh dengan rumus :

$$
\mathrm{CAR}=\frac{\mathrm{M}}{\mathrm{A}^{\prime}} \times 100 \%
$$

Dalam penelitian ini dana pihak ketiga pada BPR Kabupaten Badung Periode 2014-2016 berdasarkan rumus adalah sebagai berikut.

Dana Pihak Ketiga $=$ Total tabungan + Total deposito

Dalam penelitian ini bank size pada BPR Kabupaten Badung Periode 20142016, diukur berdasarkan rumus sebagai berikut :

Size Bank $=$ Ln (Total aset bank)

Dalam penelitian ini LDR pada BPD Kabupaten Badung Periode 20142016 berdasarkan rumus menurut SE BI Nomor 3/30/DPNP tanggal 14 Desember 2001 LDR sebagai berikut :

$$
L=\frac{J n \quad h K \quad y \quad D}{T \quad D \quad P h a K} x 100 \%
$$

Populasi dalam penelitian ini adalah seluruh BPR di Kabupaten Badung periode 2014-2016 yaitu berjumlah 52 BPR. Metode penentuan sampel yang digunakan dalam penelitian ini adalah menggunakan metode purposive sampling karena tidak semua memiliki kriteria sesuai dengan fenomena yang diteliti. Maka peneliti menggunakan kriteria khusus sebagai syarat populasi yakni BPR di Kabupaten Badung yang masih aktif dapat dijadikan sampel sesuai dengan tujuan penelitian yaitu berjumlah 48 BPR di Kabupaten Badung. 
Metode pengumpulan data yang digunakan dalam penelitian ini adalah metode observasi non partisipan. Sugiono (2010: 204) menyatakan bahwa metode observasi non partisipan merupakan metode pengumpulan data dengan observasi atau pengamatan dimana peneliti tidak terlibat secara langsung dan hanya sebagai pengamat independen. Data-data yang diperlukan berupa laporan keuangan yang diperoleh dengan cara mengakses www.ojk.go.id.

Analisis dalam penelitian ini diolah menggunakan program SPSS. Teknik analisis linear berganda digunakan untuk menggambarkan satu variabel terikat dihubungkan dengan dua atau lebih variabel bebas yaitu (Utama, 2016:77) :

$\mathrm{Y}=\alpha+\beta_{1} \mathrm{X}_{1}+\beta_{2 .} \mathrm{X}_{2}+\beta_{3} . \mathrm{X}_{3}+\beta_{4} \mathrm{X}_{4}+e$

Keterangan :

$$
\begin{aligned}
& \mathrm{Y}=\text { Profitabilitas } \\
& \alpha=\text { Konstan } \\
& \beta=\text { Koefisien Regresi } \\
& \mathrm{X}_{1}=\text { Capital adequacy ratio } \\
& \mathrm{X}_{2}=\text { Dana Pihak Ketiga } \\
& \mathrm{X}_{3}=\text { Ukuran Bank } \\
& \mathrm{X}_{4}=\text { Loan to deposit ratio } \\
& e=\text { Variabel Penganggu (Residual Error) }
\end{aligned}
$$

\section{HASIL PENELITIAN DAN PEMBAHASAN}

Statistik deskripsi variabel penelitian menyampaikan informasi mengenai karakteristik variabel-variabel penelitian yang terdari dari jumlah pengamatan, nilai minimum, nilai maksimum, nilai rata-rata dan standar deviasi. Hasil analisis statistik deskriptif dalam penelitian ini disajikan dalam Tabel 1. 
Tabel 1.

Statistik Deskriptif

\begin{tabular}{lccccc}
\hline & N & Minimum & Maximum & Mean & $\begin{array}{c}\text { Std. } \\
\text { Deviation }\end{array}$ \\
\hline ROA & 144 & -3.321 & 12.865 & 3.22191 & 2.382535 \\
CAR & 144 & 0.416 & 43.722 & 10.1336 & 7.801607 \\
DPK & 144 & 4621482 & 305352079 & 28723423 & 37130000 \\
Size Bank & 144 & 15.93 & 20.04 & 17.41576 & 0.776468 \\
LDR & 144 & 64.86 & 277.052 & 147.6028 & 44.71826 \\
Valid N & 144 & & & & \\
(listwise) & & & & \\
\hline \multicolumn{5}{l}{ Sumber: Data diolah, 2018 }
\end{tabular}

Berdasarkan hasil uji statistik deskriptif pada Tabel 1, menunjukkan jumlah data pengamatan yang digunakan sebanyak 144 (n). Selain itu data dalam Tabel 1 juga menunjukkan informasi bahwa profitabilitas paling rendah (minimum) adalah sebesar -3,321 dimiliki oleh PT. BPR Bukit Tanjung pada tahun 2016. Nilai profitabilitas yang paling tinggi (maksimum) adalah sebesar 12,865 yang dimiliki oleh PT. BPR Jaya Kerti pada tahun 2015. Profitabilitas memiliki nilai rata-rata sebesar 3,22191 dengan nilai standar deviasi sebesar 2,3825. Ini berarti bahwa terjadi perbedaan nilai profitabilitas yang diteliti terhadap nilai rata-ratanya sebesar 2,3825, yang artinya bahwa nilai mean lebih besar dari pada standar deviasi, sehingga mengindikasikan bahwa hasil yang cukup baik.

CAR paling rendah (minimum) adalah sebesar 0,416 dimiliki oleh PT. BPR Siwi Sedana pada tahun 2014 dan CAR yang paling tinggi (maksimum) adalah sebesar 43,722 yang dimiliki oleh PT. BPR Mambal pada tahun 2016. CAR memiliki nilai rata-rata sebesar 10,1336 dengan nilai standar deviasi sebesar 7,8016. Ini berarti bahwa terjadi perbedaan nilai CAR yang diteliti terhadap nilai rata-ratanya sebesar 7,8016, yang artinya bahwa nilai mean lebih besar dari pada standar deviasi, sehingga mengindikasikan bahwa hasil yang cukup baik. 
DPK paling rendah (minimum) adalah sebesar 4.621.482 dimiliki oleh PT. BPR Siwi Sedana pada tahun 2014 dan DPK yang paling tinggi (maksimum) adalah sebesar 305.352.079 yang dimiliki oleh PT. BPR Kita Centradana pada tahun 2016. DPK memiliki nilai rata-rata sebesar 28.723.422 dengan nilai standar deviasi sebesar 37.130.000. Ini berarti bahwa terjadi perbedaan nilai DPK yang diteliti terhadap nilai rata-ratanya sebesar 37.130.000, yang artinya bahwa nilai mean lebih kecil daripada standar deviasi, sehingga mengindikasikan bahwa hasil yang kurang baik. Sebab standar deviasi merupakan pencerminan penyimpangan yang sangat tinggi, sehingga penyebaran data menunjukkan hasil yang tidak normal dan menyebabkan bias.

Ukuran bank paling rendah (minimum) adalah sebesar 15,930 dimiliki oleh PT. BPR Karya Artha pada tahun 2015 dan ukuran bank yang paling tinggi (maksimum) adalah sebesar 20,040 yang dimiliki oleh PT. BPR Kita Centradana pada tahun 2016. Ukuran bank memiliki nilai rata-rata sebesar 17,415 dengan nilai standar deviasi sebesar 0,7765 . Ini berarti bahwa terjadi perbedaan nilai ukuran bank yang diteliti terhadap nilai rata-ratanya sebesar 0,7765 , yang artinya bahwa nilai mean lebih besar dari pada standar deviasi, sehingga mengindikasikan bahwa hasil yang cukup baik.

LDR paling rendah (minimum) adalah sebesar 64,860 dimiliki oleh PT. BPR Calliste Bestari pada tahun 2016. Nilai LDR yang paling tinggi (maksimum) adalah sebesar 277,052 yang dimiliki oleh PT. BPR Mambal pada tahun 2014. LDR memiliki nilai rata-rata sebesar 147,602 dengan nilai standar deviasi sebesar 44,718. Ini berarti bahwa terjadi perbedaan LDR yang diteliti terhadap nilai rata- 
ratanya sebesar 44,718, yang artinya bahwa nilai mean lebih besar dari pada standar deviasi, sehingga mengindikasikan bahwa hasil yang cukup baik.

Analisis regresi linier berganda ini digunakan untuk menganalisis pengaruh CAR $\left(\mathrm{X}_{1}\right)$, DPK $\left(\mathrm{X}_{2}\right)$, Ukuran Bank $\left(\mathrm{X}_{3}\right)$, LDR $\left(\mathrm{X}_{4}\right)$, pada Profitabilitas $(\mathrm{Y})$. Analisis regresi linear berganda diolah dengan bantuan software SPSS 22 for Windows dengan hasil yang dapat dilihat pada Tabel 2.

Tabel 2.

Rangkuman Hasil Analisis Regresi Linear Berganda

\begin{tabular}{|c|c|c|c|c|c|}
\hline \multirow{2}{*}{ Variabel } & \multicolumn{2}{|c|}{$\begin{array}{c}\text { Unstandardized } \\
\text { Coefficients }\end{array}$} & \multirow{2}{*}{$\begin{array}{c}\text { Standardized } \\
\text { Coefficients } \\
\text { Beta }\end{array}$} & \multirow[t]{2}{*}{$\mathbf{t}$} & \multirow[t]{2}{*}{ Sig. } \\
\hline & B & $\begin{array}{l}\text { Std. } \\
\text { error }\end{array}$ & & & \\
\hline (constant) & -14.757 & 5.893 & & -2.504 & 0.013 \\
\hline Capital Adequacy Ratio & 0.108 & 0.023 & 0.354 & 4.774 & 0 \\
\hline Dana Pihak Ketiga & $-2.46 \mathrm{E}-09$ & 0 & -0.038 & -0.324 & 0.746 \\
\hline Ukuran Bank & 0.891 & 0.36 & 0.29 & 2.476 & 0.014 \\
\hline Loan to Deposit Ratio & 0.01 & 0.004 & 0.184 & 2.345 & 0.02 \\
\hline
\end{tabular}

Dari hasil analisis regresi linear berganda pada Tabel 2 tersebut, maka dapat dibuat persamaan sebagai berikut:

$$
Y=-14,757+0,354 X_{1}-0,038 X_{2}+0,290 X_{3}+0,184 X_{4}
$$

Berdasarkan persamaan di atas, dapat dijelaskan bahwa nilai konstanta sebesar 14,757, jika nilai CAR $\left(\mathrm{X}_{1}\right)$, DPK $\left(\mathrm{X}_{2}\right)$, Ukuran bank $\left(\mathrm{X}_{3}\right)$, dan LDR $\left(\mathrm{X}_{4}\right)$ sama dengan nol, maka Profitabilitas (Y) tidak meningkat atau sama dengan 14,757. $\beta_{1}=0,354$, jika nilai CAR $\left(\mathrm{X}_{1}\right)$ bertambah, maka nilai dari Profitabilitas (Y) akan bertambah sebesar 0,354 dengan asumsi variabel bebas lainnya konstan. $\beta_{2}=-0,038$, jika nilai DPK $\left(\mathrm{X}_{2}\right)$ bertambah, maka nilai dari Profitabilitas $(\mathrm{Y})$ akan berkurang sebesar 0,038 dengan asumsi variabel bebas lainnya konstan. $\beta_{3}=$ 0,290, jika nilai Ukuran bank $\left(\mathrm{X}_{3}\right)$ bertambah, maka nilai dari Profitabilitas (Y) 
akan bertambah sebesar 0,290 dengan asumsi variabel bebas lainnya konstan. $\beta_{4}=$ 0,184, jika nilai LDR $\left(\mathrm{X}_{4}\right)$ bertambah, maka nilai dari Profitabilitas (Y) akan bertambah sebesar 0,184 dengan asumsi variabel bebas lainnya konstan.

Uji kelayakan model atau yang lebih populer disebut sebagai uji $\mathrm{F}$ (uji simultan model) merupakan tahapan awal mengidentifikasi model regresi yang diestimasi layak atau tidak digunakan untuk menjelaskan pengaruh variabelvariabel bebas terhadap variabel terikat. Hasil uji kelayakan model atau uji simultan dalam penelitian ini ditunjukkan dalam Tabel 3 berikut:

Tabel 3.

Hasi Uji Simultan (Uji F)

\begin{tabular}{ll|rrrrr}
\hline \multirow{2}{*}{ Model } & & $\begin{array}{c}\text { Sum of } \\
\text { Squares }\end{array}$ & Df & $\begin{array}{c}\text { Mean } \\
\text { Square }\end{array}$ & \multicolumn{1}{c}{ F } & \multirow{2}{*}{ Sig. } \\
\hline \multirow{3}{*}{1} & Regression & 235.548 & 4 & 58.887 & 14.206 & $.000^{\mathrm{a}}$ \\
& Residual & 576.188 & 139 & 4.145 & & \\
\hline & Total & 811.736 & 143 & & & \\
\hline
\end{tabular}

Sumber: Data diolah, 2018

Hasil uji F (Ftest) pada Tabel 3 menunjukkan bahwa nilai F Hitung sebesar 14,206 dengan nilai signifikansi P value 0,000 yang lebih kecil dari $\alpha=0,05$, ini berarti model yang digunakan pada penelitian ini adalah layak. Hasil ini memberikan makna bahwa seluruh variabel independen mampu memprediksi atau menjelaskan fenomena Profitabilitas BPR di Kabupaten Badung. Hal ini berarti model dapat digunakan untuk analisa lebih lanjut atau dengan kata lain model dapat digunakan untuk memproyeksikan karena hasil goodness of fit baik dengan nilai signifikansi P value 0,000.

Mengetahui dan mengukur kemampuan model dalam menerangkan variasi variabel independen digunakan koefisien determinasi $\left(\mathrm{R}^{2}\right)$. Peneliti menggunakan nilai adjusted $\mathrm{R}^{2}$ pada saat mengevaluasi yang mana model regresi terbaik, karena 
tidak seperti $\mathrm{R}^{2}$, nilai adjusted $\mathrm{R}^{2}$ dapat naik atau turun apabila satu variabel independen ditambahkan ke dalam model. Hasil uji koefisien determinasi dalam penelitian ini disajikan dalam Tabel 4 sebagai berikut:

Tabel 4.

Hasi Uji Koefisien Determinasi

\begin{tabular}{rrrrr}
\hline Model & R & R Square & \multicolumn{1}{c}{$\begin{array}{c}\text { Adjusted R } \\
\text { Square }\end{array}$} & \multicolumn{1}{c}{$\begin{array}{c}\text { Std. Error of the } \\
\text { Estimate }\end{array}$} \\
\hline & $.539^{\mathrm{a}}$ & 0.29 & 0.27 & 2.035986 \\
\hline
\end{tabular}

Sumber: Data diolah, 2018

Hasil uji memberikan hasil dimana diperoleh besarnya adjusted $\mathrm{R}^{2}$ (koefisien determinasi yang telah disesuaikan) pada Tabel 4 adalah 0,270. Ini berarti variasi profitabilitas BPR di Kabupaten Badung dapat dipengaruhi secara signifikan oleh variabel CAR $\left(\mathrm{X}_{1}\right)$, DPK $\left(\mathrm{X}_{2}\right)$, Ukuran Bank $\left(\mathrm{X}_{3}\right)$, dan LDR $\left(\mathrm{X}_{4}\right)$ sebesar 27 persen sedangkan sisanya sebesar 73 persen dijelaskan oleh faktorfaktor lain.

Hasil analisis regresi menunjukkan bahwa CAR secara statistik berpengaruh positif dan signifikan pada profitabilitas BPR di Kabupaten Badung selama periode 2014-2016. CAR merupakan indikator terhadap kemampuan bank untuk menutupi penurunan aktivanya sebagai akibat dari kerugian-kerugian bank yang disebabkan oleh aktiva berisiko (Dendawijaya, 2005:121). Meningkatnya capital adequacy ratio akan menyebabkan bertambahnya profitabilitas yang diperoleh bank. Hal ini mengindikasikan bahwa semakin besar CAR maka ROA yang akan diperoleh bank semakin besar, karena semakin tinggi CAR maka semakin baik kemampuan bank tersebut untuk menanggung risiko dari setiap kredit/aktiva produktif yang berisiko, sehingga kinerja bank juga akan meningkat. Sebaliknya jika CAR menurun maka ROA yang akan diperoleh juga menurun sehingga 
kinerja bank juga akan menurun. Hasil penelitian ini sesuai dengan hasil penelitian yang dilakukan oleh Mahardian (2008), Purwana (2009), Sapariyah (2010), Sudiyatno (2010) menemukan bahwa CAR berpengaruh positif dan signifikan terhadap ROA. Hasil serupa juga ditemukan oleh Munthopa, Andrew Lipunga (2014) dan M. Puspitasari Devi and J. Setiadi Nugroho (2015) bahwa Capital Adequacy Ratio berpengaruh positif dan signifikan terhadap ROA.

Hasil analisis regresi menunjukkan bahwa DPK secara statistik tidak berpengaruh signifikan terhadap Profitabilitas BPR di Kabupaten Badung selama periode 2014-2016. Secara teori sumber DPK merupakan sumber dana terpenting bagi kegiatan operasi suatu bank dan merupakan ukuran keberhasilan bank jika mampu membiayai operasinya dari sumber dana ini (Kasmir, 2012). Pentingnya sumber dana dari masyarakat luas disebabkan sumber dana dari masyarakat luas merupakan sumber dana yang paling utama bagi bank. Dana-dana yang dihimpun dari masyarakat merupakan sumber dana yang terbesar yang paling diandalkan oleh Bank. Bank bertugas memberikan pelayanan kepada masyarakat dan berada di tengah masyarakat agar arus uang dari masyarakat yang kelebihan dana dapat disalurkan kepada pihak yang kekurangan dana (Rusdiana, 2012). DPK adalah pangsa pasar dana pihak ketiga yang dihimpun oleh masing-masing bank secara indvidu. Semakin tinggi rasio ini, maka semakin baik tingkat kepercayaan masyarakat terhadap bank yang bersangkutan. Hasil analisis yang menunjukkan DPK tidak berpengaruh pada profitabilitas. Hal ini menunjukkan bahwa semakin besar DPK yang dimiliki oleh suatu bank, belum tentu mencerminkan laba yang besar yang akan diperoleh bank tersebut. 
DPK tidak berpengaruh terhadap profitabilitas disebabkan ketidakseimbangan antara jumlah sumber dana yang masuk dengan jumlah kredit yang diberikan kepada masyarakat. Semakin tinggi DPK yang terkumpul di bank namun tidak dimbangi dengan penyaluran kredit, maka kemungkinan bank mengalami kerugian atau penurunan profitabilitas, karena pendapatan bunga dari penyaluran kredit kepada debitur tidak mencukupi untuk menutup biaya bunga yang harus dibayarkan kepada deposan. Walaupun penghimpunan dana pihak ketiga yang cukup signifikan, tetapi tidak diimbangi dengan penyaluran kredit yang baik maka profit/laba bank pun akan terhambat. Hal tersebut dapat terjadi karena alokasi dana yang terhimpun bank belum sepenuhnya dapat dioptimalkan untuk menghasilkan profit/laba bagi bank yang mengakibatkan terjadinya pengendapan dana. Salah satu faktor penyebab ketidakseimbangan antara jumlah sumber dana yang masuk dan jumlah kredit yang dilemparkan kepada masyarakat karena adanya faktor ketidakpercayaan masyarakat kepada pihak bank untuk mengelola uang mereka dalam kegiatan operasional bank seperti pemberian kredit. Kondisi ini menunjukkan bahwa masyarakat masih belum percaya sepenuhnya kepada pihak bank untuk menyimpan dan mengelola uangnya karena adanya rasa khawatir apabila sewaktu-waktu pihak bank tidak mampu mengembalikan dana yang telah diserahkan ke bank.

Hasil penelitian ini sesuai dengan hasil penelitian yang dilakukan oleh Sukmawati dan Purbawangsa (2016) yang menyatakan bahwa DPK tidak memiliki pengaruh yang signifikan terhadap Profitabilitas dengan menggunakan 
rasio Return On Asset. Dalam hal ini, DPK tidak menjamin tingkat perubahan Return On Asset.

Hasil analisis regresi menunjukkan bahwa Ukuran bank secara statistik berpengaruh positif dan signifikan pada Profitabilitas BPR di Kabupaten Badung selama periode 2014-2016. Menurut Kosmidou et al. (2008), bank yang lebih besar ukuran assetnya lebih menguntungkan daripada bank yang ukuran assetnya kecil karena ukuran bank yang lebih besar mempunyai tingkat efisiensi yang lebih tinggi. Ukuran bank dapat dinyatakan dengan total aktiva, penjualan dan kapitalisasi pasar. Ketiga variabel ini digunakan untuk menentukan ukuran bank karena dapat mewakili seberapa besar bank tersebut. Hasil penelitian ini konsisten dengan hasil penelitian Manuaba (2012), dan Raj Bhattarai (2016), yang menyatakan bahwa ukuran bank berpengaruh positif dan signifikan terhadap ROA. Penelitian ini juga di dukung oleh penelitian Trujillo Antonio, Ponce (2013) yang menemukan bahwa ukuran bank berpengaruh positif terhadap ROA. Hal ini mengindikasikan bahwa semakin besar ukuran bank, maka profitabilitas yang akan diperoleh akan semakin besar.

Hasil analisis regresi menunjukkan bahwa LDR secara statistik berpengaruh positif dan signifikan pada profitabilitas BPR di Kabupaten Badung selama periode 2014-2016. Secara teori LDR merupakan kemampuan bank dalam membayar kembali penarikan dana yang dilakukan deposan dengan mengandalkan kredit yang diberikan sebagai sumber likuiditasnya (Dendawijaya, 2005:116). Bila dilihat dari hubungannya, antara LDR dengan profitabilitas memiliki hubungan positif (searah). Pernyataan tersebut mengindikasikan bahwa 
semakin tinggi LDR maka laba perusahaan semakin meningkat dengan asumsi bank tersebut mampu menyalurkan kredit dengan efektif, sehingga jumlah kredit macetnya akan kecil. Hal ini menunjukkan bahwa semakin tinggi LDR sampai dengan batas tertentu maka akan semakin banyak dana yang disalurkan dalam bentuk kredit maka akan meningkatkan pendapatan bunga sehingga ROA semakin tinggi. Hasil penelitian ini sesuai dengan hasil penelitian yang dilakukan oleh Dewi dan Suartana (2008), Mahardian (2008), Purwana (2009), Susanthi (2010), Sapariyah (2010), dan Jantarini (2010) yang menemukan hasil bahwa LDR berpengaruh signifikan terhadap ROA.

Implikasi dari hasil penelitian ini yaitu hasil penelitian yang sudah dilakukan ini diharapkan dapat memberikan kontribusi mengenai pengaruh CAR, DPK, Ukuran Bank, dan LDR pada profitabilitas. Hasil uji hipotesis dalam penelitian ini ditemukan bahwa DPK tidak berpengaruh signifikan pada profitabilitas. Bank yang tidak mampu menghimpun dana pihak ketiga yang diimbangi dengan penyaluran kredit yang baik maka profit/laba bank pun akan terhambat. Hal tersebut dapat terjadi karena alokasi dana yang terhimpun bank belum sepenuhnya dapat dioptimalkan untuk menghasilkan profit/laba bagi bank yang mengakibatkan terjadinya pengendapan dana. Oleh karena itu bank sebaiknya mampu menghimpun DPK yang diimbangi dengan penyaluran kredit yang baik.

\section{SIMPULAN DAN SARAN}

Berdasarkan hasil analisis penelitian dan hasil pembahasan maka simpulan dari penelitian ini adalah CAR berpengaruh positif dan signifikan pada 
profitabilitas BPR di Kabupaten Badung selama periode 2014-2016. Hasil penelitian ini menunjukkan bahwa semakin besar CAR maka ROA yang akan diperoleh bank semakin besar, karena semakin tinggi CAR maka semakin baik kemampuan bank tersebut untuk menanggung risiko dari setiap kredit/aktiva produktif yang berisiko, sehingga kinerja bank bertambah dan profitabilitas menjadi meningkat.

DPK tidak berpengaruh signifikan terhadap Profitabilitas BPR di Kabupaten Badung selama periode 2014-2016. Hal ini menunjukkan bahwa perubahan pada DPK tidak akan berpengaruh pada profitabilitas. Semakin tinggi dana pihak ketiga yang terkumpul di bank namun tidak dimbangi dengan penyaluran kredit, maka kemungkinan bank mengalami kerugian atau penurunan profitabilitas, karena pendapatan bunga dari penyaluran kredit kepada debitur tidak mencukupi untuk menutup biaya bunga yang harus dibayarkan kepada deposan. Hal tersebut dapat terjadi karena alokasi dana yang terhimpun bank belum sepenuhnya dapat dioptimalkan untuk menghasilkan profit/laba bagi bank yang mengakibatkan terjadinya pengendapan dana.

Ukuran bank berpengaruh positif dan signifikan terhadap Profitabilitas BPR di Kabupaten Badung selama periode 2014-2016. Hasil penelitian ini mengindikasikan bahwa semakin besar ukuran bank, maka profitabilitasnya juga semakin besar.

LDR berpengaruh positif dan signifikan terhadap Profitabilitas BPR di Kabupaten Badung selama periode 2014-2016. Hasil penelitian ini mengindikasikan bahwa semakin tinggi LDR maka profitabilitas perusahaan 
semakin meningkat dengan asumsi bank tersebut mampu menyalurkan kredit dengan efektif, sehingga jumlah kredit macetnya akan kecil. Hal ini menunjukkan bahwa semakin tinggi LDR sampai dengan batas tertentu maka akan semakin banyak dana yang disalurkan dalam bentuk kredit maka akan meningkatkan pendapatan bunga sehingga ROA semakin tinggi.

Berdasarkan hasil analisis penelitian, pembahasan dan kesimpulan terdapat beberapa saran yang dapat dipergunakan sebagai bahan pertimbangan dalam menentukan kebijakan terkait faktor-faktor yang mempengaruhi Profitabilitas BPR di Kabupaten Badung selama periode 2014-2016 dimasa mendatang, antara lain hasil menunjukkan CAR, Ukuran Bank, dan LDR terbukti berpengaruh positif pada profitabilitas bank BPR di Kabupaten Badung. Sejalan dengan hasil penelitian ini diharapkan bank selalu menjaga kesehatan bank dengan menjaga komponen CAR, Ukuran Bank, dan LDR sesuai dengan standar yang ditetapkan oleh Bank Indonesia sebagai otoritas bank di seluruh Indonesia.

Hasil penelitian menunjukkan bahwa DPK tidak bepengaruh terhadap profitabilitas, oleh karena itu bank hendaknya lebih memperhatikan lagi pengelolaan DPK yang dimilikinya dan mampu menghimpun DPK yang diimbangi dengan penyaluran kredit yang baik. Dengan demikian, tingkat profitabilitas yang diperoleh bank akan meningkat.

Penelitian selanjutnya dapat mempertimbangkan untuk menggunakan ukuran profitabilitas lainnya atau objek penelitian selain BPR di Kabupaten Badung selama periode 2014-2016. Penelitian selanjutnya diharapkan dapat menambah jumlah sampel perusahaan yang akan dijadikan sampel penelitian. 


\section{REFERENSI}

Alper, Deger dan Adem Anbar (2011). Bank Specific and Macroeconomic Determinants of Commercial Bank Profitability: Empirical Evidence From Turkey. Business and Economics Research Journal. 2(2): pp: 139-152

Al-Qudah, Ali Mustafa and Mahmoud Ali Jaradat. (2013). The Impact of Macroeconomic Variables and Banks Characteristics on Jordanian Islamic Banks Profitability: Empirical Evidence. International Business Research. 6(10): pp: 153-162.

Anggreni, Made Ria dan I Made Sadha Suardhika. (2014). Pengaruh Dana Pihak Ketiga, Kecukupan Modal, Risiko Kredit, dan Suku Bunga Kredit pada Profitabilritas. E-Jurnal Akuntansi Universitas Udayana. 9.1. hal: 27-38.

Aremu, Mukaila Ayanda, Imoh Christopher and Mustapha Adeniyi Mudashiru. (2013). Determinants of Bank's Profitability in a developing Economy: Evidence From Nigerian Banking Industry. Journal of Contemporary Research in Business. 4(9): h: 155-181.

Brigham dan Huston. (2006). Fundamental of Financial Management: DasarDasar Manajemen Keuangan. Edisi 10. Jakarta: Salemba Empat.

Buchory Achmad Herry. (2015). Banking Internediation, Operational Efficiency And Risk In The Banking Profitability. International Journal of Business, Economics and Law, Vol. 7, Issue 2 (Aug.).ISSN 2289-1552, pp.57 - 63.

Cahyadi, Putu. (2014). Pengaruh Cash Turnover, Loan to Deposit Ratio, Capital Adequacy Ratio dan Dana Pihak Ketiga terhadap Profitabilitas LPD. EJurnal Manajemen Universitas Udayana. 8(2), pp:101-108.

Dendawijaya, Lukman. (2009). Manajemen Perbankan. Bogor. Ghalia Indonesia.

Dewi, Putu Nila Krisna dan I Wayan Suartana. (2008). Pengaruh Pertumbungan Aktiva Produktif dan Dana Pihak Ketiga Pada Kinerja Operasional Lebaga Perkreditan Desa di Kabupaten Badung. Dalam Jurnal Akuntansi Fakultas Ekonomi Universitas Udayana.

Dhanuskodi Rengasamy. (2014). Impact of Loan Deposit Ratio (LDR) on Profitability: Panel Evidence from Commercial Banks in Malaysia. Proceedings of the Third International Conference on Global Business, Economics, Finance and Social Sciences (GB14Mumbai Conference) Mumbai, India.ISBN: 978-1-941505-21-2 Paper ID: MF498,Pp. 1 - 12.

Eka Suputra, I Putu, Cipta, Wayan dan Yulianthini, Ni Nyoman. (2014). Pengaruh Dana Pihak Ketiga (DPK), Penyaluran Kredit dan Kredit Bermasalah Terhadap Profitabilitas Pada Lembaga Perkreditan Desa (LPD) Kecamatan Karangasem. E-Journal Bisma Universitas Pendidikan Ganesha Jurusan Manajemen. Volume 2. 
Fahmi, Irham. (2012). Pengantar Manajemen Keuangan. Bandung: Alfabeta.

Febrianto, Dwi Fajar \& Dul Muid. (2013). Analisis Pengaruh Dana Pihak Ketiga, LDR, NPL, CAR, ROA, dan BOPO terhadap Jumlah Penyaluran Kredit (Studi pada Bank Umum yang Terdaftar Di Bursa Efek Indonesia Periode Tahun 2009-2012). Dipenogoro Journal of Accounting, 2 (4) hal: 1-11.

Folorunsho Monsuru Ajide. (2014). The effects of corporate social responsibility activity disclosure on corporate profitability: Empirical evidence from Nigerian commercial banks: IOSR Journal of Economics and Finance (IOSR-JEF) e-ISSN: 2321-5933, p-ISSN: 2321-5925.Volume 2, Issue 6 (Feb. 2014), PP 17-25.

Irianti, Tjiptowati Endang. (2011). Pengaruh Rasio Kecukupan Modal, Likuiditas, Dan Total Dana Pihak Ketiga Terhadap Tingkat Profitabilitas Perusahaan Perbankan. Jurnal Ilmiah Inkoma, 24 (1).

Jantarini, Dwi. (2010). Pengaruh Capital Adequacy Ratio, Non Performing Loan,Loan to Deposit Ratio dan Kualitas Aktiva Produktif terhadap Profitabilitas pada PT Bank yang Go Public di Indonesia Periode 20072009. Jurusan Akuntansi Fakultas Ekonomi Universitas Udayana, Denpasar.

Kasmir. (2014). Manajemen Perbankan. Edisi Revisi. Cetakan 12. Jakarta: Rajawali Pers.

Kosmidou, Kyriaki and Constantin Zopounidis. (2008). Measurement of Bank Performance in Greece. South-Eastern Europe Journal of Economics. 1(1), pp: 79-95.

Lukman, Wijaya. (2005). Pengaruh Kecukupan Modal, Penyaluran Kredit dan Efisiensi Operasional Terhadap Profitabilitas Bank Yang Terdaftar Di Bursa Efek Indonesia. Fakultas Ekonomi Universitas Gajah Mada.

M. Puspitasari Devi , and J. Setiadi Nugroho. (2015). Implementation On The Indonesia Banking Architecture As A Blueprint Of The Direction And Order Of The National Banking System : Empirical Study Of Indonesian Commercial Banking. Journal The Winners. Vol. 16 No. 1, pp 6-14.

Manuaba, Ida Bagus Pranabawa Adi Kencana. (2012). Pengaruh Capital Adequacy Ratio, Non Performing Loan, Ukuran Perusahaan dan Struktur Kepemilikan terhadap Profitabilitas Bank yang Terdaftar di Bursa Efek Indonesia Tahun 2008-2011. Fakultas Ekonomi Universitas Udayana. pp:1-17.

Mahardian, Pandu. (2008). Pengaruh Capital Adequacy Ratio (CAR), Efisiensi Operasi (BOPO), Non Performing Loan (NPL), Net Interest Margin (NIM), dan Loan to Deposit Ratio (LDR) terhadap Return on Asset (ROA) sebagai proksi dari Kinerja Keuangan Perusahaan Perbankan yang 
Tercatat di BEJ periode Juni 2002 hingga Juni 2007. Tesis. Program Studi Manajemen Pasca Sarjana Universitas Dipenogoro.

Maredza Andrew. (2014). Internal Determinants Of Bank Profitability In South Africa: Does Bank Efficiency Matter?. International Business \& Economics Research Journal, Volume 13, Number 5, pp. 1033-1046.

Munthopa, Andrew Lipunga. (2014). Determinants of Profitability of Listed Commercial Bank in Developing Countries: Evidence from Malawi. Research Journal of Finance and Accounting. Volume 5 No. 6. Pp: 41-49.

Munawir, S. (2010). Analisa Laporan Keuangan. Edisi Keempat Libert. Yogyakarta.

Nawaf Ahmad Salem Alghusin. (2015). Do Financial Leverage, Growth And Size Affect Profitability Of Jordanian Industrial Firms Listed. International Journal Of Academic Research In Business And Social Sciences. Vol. 5 (4),Pp.385-398.

Nuritomo dan Totok Budisantoso. (2014). Bank dan Lembaga Keuangan. Jakarta : Salemba Empat.

Prasnanugraha, P. (2007). Analisis Pengaruh Rasio-Rasio Keuangan terhadap KinerjaBank Umum di Indonesia(Studi Empiris Bank-Bank Umum yang Beroperasi di Indonesia). Tesis. Program Studi Magister Sains Akuntansi, Program Pascasarjana, Universitas Diponegoro, Semarang.

Purwana, Edward Gagah. (2009). Pengaruh Capital Adequacy Ratio (CAR), Loan to Deposit Ratio (LDR), Size, BOPO, Profitabilitas, Chow Test (Studi Perbandingan Pada Bank Domestik dan Bank Asing Periode Januari 2003Desember 2007). Tesis. Program Studi Manajemen Pasca Sarjana Universitas Dipenogoro.

Raheem Anser, Qaisar Ali Malik. (2013). Cash Conversion Cycle and Firms' Profitability - A Study of Listed Manufacturing Companies of Pakistan. Journal of Business and Management. 8(2): h: 83-87.

Raj Bhattarai Dr.Yuga. (2016). Effect of Non-Performing Loan on the Profitability of Commercial Banks in Nepal. The International Journal Of Business \& Management. Vol. 4(6) .pp. 435-442.ISSN 2321-8916.

Rashid, Afsalur and A. Z. M. Anisur Rahman. (2008). Dividen Policy and Stock Price Volatility: Evidence From Bangladesh. Journal of Applied Business and Economics. 8(4), pp: 1-11.

Ratnawati, Kusuma, Esther Novelina Hutagalung, dan Djumahir. (2013). Analisis Rasio Keuangan terhadap Kinerja Bank Umum di Indonesia. Jurnal Aplikasi Manajemen, 11 (1), pp: 122-130.

Rusdiana. Nana. (2012). "Analisis pengaruh CAR,LDR,NIM,NPL,BOPO dan DPK terhadap kinerja keuangan perbankan (Studi Kasus pada Bank 
Umum yang terdaftar pada Bursa Efek Indonesia Periode 2008-2011)". Universitas Diponegoro.

Sajid Saeed Muhammad. (2014). Bank-related, Industry-related and Macroeconomic Factors Affecting Bank Profitability: A Case of the United Kingdom : Research Journal of Finance and Accounting ISSN 2222-1697 (Paper) ISSN 2222-2847.

Sari, Greydi Normala. (2013). Faktor-faktor yang Mempengaruhi Penyaluran Kredit Bank Umum di Indonesia (Periode 2008.1 - 2012.2). Jurnal EMBA, 1 (3): 931-941.

Sapariyah, Rina Ani. (2010). Pengaruh Rasio Capital, Assets, Earning, dan Liquidity terhadap pertumbuhan laba perbankan di Indonesia. Dalam Jurnal Nasional STIE AUB Surakarta. Vol. 18, No.13.

Setiadi, Pompong B. (2010). Analisis Hubungan Spread of Interest Rate, Fee Based Income, dan Loan to Deposit Ratio dengan ROA pada Perbankan di Jawa Timur. Jurnal Mitra Ekonomi dan Manajemen Bisnis. 1(1), April 2010, 63-82 STIAMAK, Surabaya.

Sudiyatno, Bambang. (2010). "Analisis Pengaruh DPK, BOPO, CAR, dan LDR terhadap Kinerja Keuangan pada Sektor Perbankan yang Go Public di Bursa Efek Indonesia (BEI) periode 2005-2008”. Jurnal Dinamika Keuangan dan Perbankan. 2(2), pp: 125-137.

Sukmawati dan Purbawangsa. (2016). Pengaruh Pertumbuhan Dana Pihak Ketiga, Pertumbuhan Kredit, Risiko Kredit, Likuiditas, dan Kondisi Ekonomi Terhadap Profitabilitas. E-Jurnal Manajemen Unud. Vol.5, No. 9. 2016:5333-5368.

Surat Edaran Bank Indonesia No. 6/23/DPNP Tanggal 31 Mei 2004 tentang Cara Penilaian Kesehatan Bank.

Susanthi, Ari. (2010). Pengaruh Loan to Deposit ratio, Capital Adequacy Ratio, dan Leverage Management terhadap Profitabilitas pada PT Bank Pembangunan Daerah Bali Kantor Pusat Denpasar. Jurusan Manajemen Fakultas Ekonomi Universitas Udayana, Denpasar.

Taswan. (2006). Manajemen Perbankan, Konsep, Teknik \& Aplikasi. Penerbit Upp Stim Ykpn Yogyakarta.

Taswan, (2010), Manajemen Perbankan,Edisi Ii,Konsep,Teknik \& Aplikasi, Penerbit Upp Stim Ykpn Yogyakarta.

Trujillo Antonio, Ponce. (2013). What determines the profitability of banks? Evidence from Spain. Accounting and Finance 53 (2013) 561-586. 
Ugur, Ahmet dan Hakan Erkus. (2010). Determinants of the Net Interest Margins of Banks in Turkey. Journal of Economic and Social Research. 12 (2) 2010, pp 101-118.

Utama, Made Suyana. (2016). Aplikasi Analisis Kuantitatif untuk Ekonomi dan Bisnis. Edisi ke 10. Denpasar: CV. Sastra Utama.

Yogi A.A. Prasanjaya dan Ramantha I Wayan. (2013). Analisis Pengaruh Rasio CAR, BOPO, LDR dan Ukuran Perusahaan Terhadap Profitabilitas Bank yang Terdaftar di BEI. E-Jurnal Akuntansi Universitas Udayana. 4.1.230245. 